Volume 7 Issue 1, March 2020

Nationally Accredited Journal,

Decree No. B/4130/E5/E5.2.1/2019

\title{
Responsibilities Of Deed Land Builders Officers (PPAT) In Making Buy And Sell Deed Land Dispute (Analysis of Supreme Court Decision No. 826 K / Pdt / 2018)
}

\begin{abstract}
Mugiyatno $^{1}$, Diyono ${ }^{2}$ and Akhmad Khisni ${ }^{3}$
Abstract. The purpose of this study was to analyze 1) Liability Land Deed Official (PPAT) in the manufacture of the deed of sale of land. 2) The validity of the deed of sale made by PPAT.3). Analyzing the legal consequences Supreme Court Decision No. $826 \mathrm{~K} /$ Pdt / 2018 against the Land Deed Official (PPAT) who manufacture a deed of sale of land disputes.

The approach method in this research is the empirical jurisdiction. Specifications of this research is descriptive analysis. The source of the data used is primary and secondary data. The primary source is the Supreme Court decision number 826K / Pdt / 2018, while secondary data sources are taken from books. obtained through interviews and literature, while data analysis is a descriptive analytic. The method of data collection is the engineering library (library research).

Results of the research results can be concluded: 1) Obligation PPAT is a deed as evidence has implemented a legal act of buying and selling, and registered under the name of the office to Pertanahan.2) Validity of PPAT Deed governed and determined by the current Minister of National Land Agency, it is affirmed in Article 21 paragraph (1) of Government Regulation No. 37 of 1998 which states that the PPAT deed made in the prescribed form of the National Land Agency. 3). The legal consequences Supreme Court Decision No. 826 K / Pdt / 2018 is the Deed of Sale and Purchase of Land Disputes number 186/2015 and certificate of land with 1394 numbers became invalid / void and not legally binding and PPAT and Land Agency may be penalized for committed an unlawful act.

Keywords : Offense; Purchase Agreement; Land Deed Official.
\end{abstract}

\section{Introduction}

Increasing people's economy and the national economy is more advanced purposes compensated by the increased legal certainty in the land sector. In everyday life are often disputed land certificates even to the court. This arises because the soil has a vital function for the life of the community. To obtain legal certainty and security of rights to land, then people need to register in order to obtain a certificate of land tenure, which serves as a strong evidence on land ownership. ${ }^{4}$ The principle is the registration guarantees rights status, guarantees of the accuracy of a list even supposed to provide compensation to those who suffered losses. ${ }^{5}$

Since its applicable PP 10 of 1961 on the sale and purchase of land registration made by the parties in the presence of PPAT charge. By doing the selling before PPAT, filled with light condition (not a legal act of the dark, which is done in secret). Deed of sale signed by the parties prove there has been a transfer of rights from the seller to the purchaser,

\footnotetext{
1 Student Master of Notary program, Faculty of Law, Sultan Agung Islamic University Semarang, email mlawassociatie@gmail.com

${ }^{2}$ Student of Master of Law Program, Faculty of Law, Universitas Islam Sultan Agung

${ }^{3}$ Faculty of Law, Sultan Agung Islamic University Semarang

${ }^{4}$ Adrian Sutedi, 2012, Sertifikat Hak Atas Tanah, Jakarta: Sinar Grafika, p. 105

${ }^{5}$ Mark P. Thompson, 2001, the Modern Land Law, First Published, Oxford University Press, New York, p. 88
} 
accompanied by payment of the price, has qualified cash and show that real or legal act of buying and selling real question has been implemented. The deed has been done to prove that the correct legal assignment for ever and payment costs. Because the legal act performed a legal act of transfer of rights, then the certificate proving that the assignee (buyer) has become the new rights holder. ${ }^{6}$ In the Regulation of the National Land Agency Number 6 of $1989^{7}$ and PP 37 of 1998, has been emphasized several legal actions which are the responsibility of PPAT, namely:

- The truth of the events contained in the deed, for example regarding the types of legal actions referred to by the parties, the payment has been done in the buying and selling, etc.

- About the object of legal actions, both physical data and data juridical

- Regarding the identity of the parties to take legal actions.

If PPAT not know personally about it, PPAT can seek the testimony of witnesses required in the deed. ${ }^{8}$ Land purchase case that ended in disputes often arise either in print, or electronic, and perhaps not publicized too much. Therefore, pre prospective buyers of land or house should know what things are supposed to be prepared in order to avoid disputes in the future. When someone buys the land, will be faced with two possibilities, the first land to be purchased have a certificate, and the second has not been certified.

Often in land transactions led to problems. In the short term the buyer probably will not experience a lawsuit from the other party, but in the long term the buyer will have others who feel they have or will be harmed their land rights. As happened to Neni Hastuti sambek village residents, district of Wonosobo, Wonosobo. He bought land and a building area of $77 \mathrm{~m} 2$ located in the village of Godean village Wonolelo, District of Wonosobo, Wonosobo. Neni Hastuti bought it in 2015 from Hartiningsih as its rightful owner, and PPAT has issued a deed of sale that on March 9, 2015, and the Land Agency has also issued the certificate. But it was in 2011 Hartiningsih already sold the land and the building to Sadnam Mairin Khana to the procedures for buying and selling according to custom, and is quiet and cash. The parties of Sadnam Mairin Khana feel aggrieved to the Court, the Court finally decided that buying and selling Neni and Hartiningsih is invalid. PPAT and Wonosobo Land Agency also alleged to have committed an unlawful act. Neni filed an appeal and cassation, but also was not granted by the Supreme Court.

Based on the above cases, the authors are keen to investigate further with the title, "Responsibility Officer Deed Land (PPAT) in Preparation of Deed of Sale and Purchase of Land Disputes (Analysis Decision of the Supreme Court Number 826 K / Pdt / 2018)." This study attempts to answer the question of how PPAT obligations in the manufacture of a deed of sale of land, the validity of the deed of sale made by PPAT, and how the legal consequences Supreme Court Decision No. 826 K / Pdt / 2018 against the land Deed official (PPAT) who manufacture a deed of sale of land disputes.

\section{Research methods}

The approach method in this research is the empirical jurisdiction. Specifications of this research is descriptive analysis. The source of the data used is primary and secondary data. The primary source is the Supreme Court decision number 826K / Pdt / 2018, while secondary data sources are taken from books and other related through interviews and literature, while data analysis is a descriptive analytic. The method of data collection is the engineering library (library research).

\footnotetext{
${ }^{6}$ Boedi Harsono, 1999, Hukum Agraria Indonesia Sejarah Pembentukan UU Pokok Agraria, Jakarta: Djambatan Boedi, p. 298

${ }^{7}$ Regulation of the National Land Agency Number 6 of 1989

${ }^{8}$ Article 18 paragraph (3) Regulation of the Minister of Agriculture of the National Land Agency Number 4 of 1999
} 
Volume 7 Issue 1, March 2020

Nationally Accredited Journal,

Decree No. B/4130/E5/E5.2.1/2019

\section{Results and Discussion}

\subsection{Obligations of Land Deed Official (PPAT) in the manufacture of the Deed of Sale and Purchase of Land}

Sale and purchase according to the Civil Code is an agreement in which one party (the seller) to bind himself to hand (property rights) of an object and the other party (the buyer) to pay the price that has been promised in accordance with Article 1457. As according to Article 1458 of buying and selling is considered to have occurred between the two sides at the time achieved consensus on the objects sold along with the price even if the object has not been submitted and the price has not been paid. With the purchase, the land ownership has not been transferred to the buyer even though the price has been paid and the land was handed over to the buyer. ${ }^{9}$

In terms of buying and selling property rights to land based on customary law, where the purchase is cash, then when the ownership entitles the buyer is at the time of buying and selling is done in the presence of PPAT. ${ }^{10}$ However, to bind third parties, including the Government, after the purchase before PPAT, must be registered in advance.

In accordance with the provisions of Article 97 of the Regulation of the Minister of State for Agrarian Affairs / Head of National Land Agency Number 3 of 1997 on 45 Provisions Implementation of Government Regulation No. 24 of 2007 on Land Registration, that before executing a deed regarding the removal or imposition of land rights or the Right of Ownership on Unit Home Compose, PPAT shall first examine the land Office on the suitability of land certificates or right of Ownership on Unit Flats is concerned with lists that exist in the local land Office by showing the original certificate.

Deed of sale of land is a very important thing that works for the transfer of property rights to land and the ownership of land. ${ }^{11}$ In order for the sale and purchase transactions can be accounted for, the presence of witnesses is also absolutely essential, because if one of the parties the seller and buyer reneges and disputed, then the two witnesses is what will explain to the judge that they really have done a land purchase.

In addition to the obligation to make a deed of sale, according to Government Regulation No.24 of 1997 Article 40 paragraph (1) and (2) states that the other obligations of the PPAT is:

- Registering documents no later than 7 business days from the date of signing the deed of sale by the person concerned, PPAT deed made shall submit the following documents to the relevant Land Office for registration.

- PPAT shall submit a written notice of already delivered the deed referred to in paragraph (1) to the parties concerned.

Meanwhile, According to Regulation of the Minister of Agrarian Affairs / Head of National Land Agency Number 12006 Article 45 states that PPAT have obligations:

- Uphold Pancasila, the Constitution of 1945, and the Republic of Indonesia

- Following the inauguration and the appointment of an oath of office as PPAT

- The monthly report on the deed of land made to the Head Office, Head of Regional Office and Head of the Tax Office of Land and local building no later than the next

\footnotetext{
${ }^{9}$ Maria SW, Sumardjono (V), 22 July 1993 Theoretical Aspects of Transfer of Rights to Land, seminar paper, 1982, Peralihan Hak-Hak Atas Tanah, Aspek Hukum dan Segi Praktek yang Aktual Dewasa ini, Jakarta: YayasanBiluta and Office Chandra Motik Djemat \& Associates, p. 53 ${ }^{10}$ Ibid, h.56

11 Harun al-Rashid, 1987, Sekilas tentang jual Beli Tanah, First Edition, Jakarta: Ghalia Indonesia, p.64.
} 
eISSN : 2581-2114, pISSN: 2406-9426

10bulan

- Submit PPAT protocol in terms of:

- PPAT who quit served as referred to in Article 28 paragraph (1) and (2) to PPAT work area or to the Head of the Land Office.

- PPAT temporary stop as PPAT While the Provisional replace or to the head of the Land Office.

- Special PPAT who quit as PPAT Lodging Special to replace or to the Head of the Land Office.

- Freeing up money services to people who can not afford, as evidenced legally.

- Opened an office every working day unless you're carrying out the statutory holiday leave or working hours at least equal to the working hours of the Local Land Office.

- Headquartered just one (1) office in the working area as specified in the appointment decision PPAT.

- Delivering the address of his office, specimen signatures, examples of initials and impression of the seal / stamp of office to the Head of Regional Office, Regent / Mayor, Chairman of the Court and Head of the Land Office, whose territory includes the work area PPAT concerned within one (1) month after the oath-taking positions.

- Implement real office after taking the oath of office.

- Signboards and using the stamp shape and size determined by the National Land Agency.

- Other appropriate legislation.

In addition PPAT must keep the contents of the deed. Article 34 paragraph (1) of the National Land Agency Number 1 of 2006 on Implementation Provisions of Government Regulation No. 37 Year 1998 on the Regulation of Land Title Deed Official, confirmed the oath of office for PPAT in order to maintain the confidentiality of the contents of the deed. Confirmed in the official oath "that I will keep secret the contents of the deed made before me, and the protocol that is my responsibility, which by their nature or by legislation to be kept confidential".

Buying and selling land by deed PPAT under PP 24 In 1997, PP 37 of 1998, and Minister of State for Agrarian Affairs / Head of National Land Agency No. 4 of 1999. Additionally, in making the deed of sale, PPAT has an obligation to pay attention to several things, including the authorities, namely: ${ }^{12}$

- Position or status of the seller is entitled to sell the land.

If the property rights to land more than one owner, it is entitled to sell are those who own the land together, and banned by one person only. Joint ownership of property rights to land that usually occur due to inheritance or was never bought jointly / together, or it never obtained jointly by the grant. Sale and purchase of land is done only by one person result null and void, meaning that from the beginning the law presumes never happened in buying and selling. In such a case, obviously very aggrieved buyer interest. Because he has already paid the land price to the seller, while their right to the land he bought was never switched to him, although it may have mastered the soil, the person entitled to the land can sue through the courts so that the land was handed over to him. The charge was very reasonable, so land buyers will be forced to vacate the land.

- Authorities seller is selling.

To be able to act as the seller must be met certain requirements, which must age of majority under the law, that is capable to perform a legal act of buying and selling land, for example:

${ }^{12}$ Effendi Perangin, 1990, Praktik jual Beli Tanah, Second Edition, Jakarta: Rajawali, p.2 
Volume 7 Issue 1, March 2020

Nationally Accredited Journal,

Decree No. B/4130/E5/E5.2.1/2019

- Children 12 years old is not authorized to purchase, although he has the right to the land. Sale and purchase happen if that act is the father of the child as the person doing parental authority.

- A piece of land in the certificate on behalf of his wife, while the land is the property along with her husband, then she is not authorized to sell its own land, but together her husband, or her husband gave written consent to his wife. Likewise, the wife to the husband must give approval if a written land as joint property on behalf of the husband. ${ }^{13}$

- If the land registered in the name, such as $X$, but the host is subject to the Civil Code are under guardianship, then authorized to sell the land it is the $X$, but must have permission from the Chairman of the Court.

- Buyers are allowed to buy the land.

Not all buyers can buy land with the status of property rights, such as limited company, limited partnership may not buy or possess. ${ }^{14}$

Another limitation of authority of the deed of sale of land should not be made by PPAT were not working area. ${ }^{15}$ Incautiousness purchase of land without going through the PPAT will cause losses on the extent of land he bought. Often the land purchase made by witnesses and letters of purchase made by the chief. Widely used a number that may very well have come from the top other certificates are not recognized measurements and calculations. Therefore, the time will be certified, the land needs to be measured, calculated and drawn then calculated acreage. The location of the boundary agreement was measured by the National Land Agency and is evidenced by the buyer's signature and adjoining land owners.

In a purchase transaction, not a few cases that arise, that is, if the transfer of the land there is a falsification of signatures is the wife consent of the seller. The demand will come from the wife to request cancellation of the transfer of rights to the land that has been reversed to the name of the buyer's name. Legal actions result in changes to land sales juridical data of land registration. ${ }^{16}$

\subsection{The validity and authenticity of the Deed of Sale and Purchase made by the Land Deed Official (PPAT)}

Validity of PPAT Deed governed and determined by the current Minister of National Land Agency, it is affirmed in Article 21 of Government Regulation No. 37 of 1998, as follows:

- PPAT Deed made with the form prescribed by the Minister.

- All kinds of PPAT deed given a serial number that is repeated at the beginning of the calendar year.

- PPAT Deed made in the original form within two (2) pieces, namely:

- The first sheet of 1 (one) copy being retained by the PPAT concerned

- a second sheet of 1 (one) double or more by the number of titles or the Right of Ownership on Unit Flats is the object of a legal act in deed, which is submitted to the Land Office for registration purposes, or in terms of the deed on giving the authority

\footnotetext{
${ }^{13}$ Article 35 and Article 36 paragraph (1) of Law No. 1 of 1974 on Marriage (State Gazette Year 1974 Number 1, Supplement to State Gazette No. 3019).

${ }^{14}$ Government Regulation No. 38 of 1963 on the appointment of Legal Persons to Have Properties Land

${ }^{15}$ Article 12 paragraph (1) of Government Regulation No. 37 of 1998.

${ }^{16}$ Irawan Soerodjo, 2003, Kepastian Hukum Hak Atas Tanah di Indonesia, First Edition, Surabaya: Arkola, p. 191
} 
to dependents, delivered to the holders of power to establish artificial base Granting

Mortgage Deed, and to the parties concerned may be given a copy.

The purpose of making a deed is to be used as proof. Its function is to ensure a legal event, with the aim of avoiding disputes. Therefore PPAT must perform a legal act of buying and selling such a way that what you want to prove it is known easily from deed made. Should be avoided, lest the deed contains the formula that may cause disputes because it is incomplete and unclear. Because the PPAT deed an authentic deed that has an absolute strength of evidence on matters or events referred to in the deed, then that is proven is uneventful.

Buying and selling land that has been created for the deed by PPAT possibility could arise problems as well, namely the linkages other parties in it to request cancellation of the transfer of rights to the land, caused initially the bad faith of one of the parties in the sale and purchase transactions the land.

To avoid the bad faith of one of the parties, the seller, should prior to the sale and purchase of land that will be created for the deed by PPAT, or in addition to the examination status of the land by PPAT, the buyer should check with them first certificate of ownership of the land, then look directly into location of the land will be bought, the buyer should ask for information to the local authorities (village) both regarding the history of ownership of the land, and who it belongs to his last, and the buyer should know the seller. ${ }^{17}$ By doing these things, the possibility of intentionally false data by the penjualalan revealed before the deed made by PPAT.

\subsection{As a result of Decision MA Law No. 826 K / Pdt / 2018 against the Land Deed Official}

Some of the causes of the cancellation of a deed of sale or certificate of land is the falsification of documents of the parties who filed a deed of sale / land certificate. One party feels for their land certificate can be filed to the District Court and prove what the truth. In the land dispute is analyzed, Defendant I and co-Defendant I had made a purchase agreement of land and a building in front of PPAT, and also has registered the land to the Land Office Wonosobo. On March 9, 2015 Wonosobo Land Office issued a certificate with the number 1394/77 m2 area (formerly the name Hartiningsih and now on behalf of Neni Hastuti), located in the village of Godean, RT 04 RW 05, Village Wonolelo, District Wonosobo,

In this case PPAT not look first to the object land and buildings made the deed of purchase. Whereas the object of land and the building has been sold first in 2011 to the late Sadnam Khana Mairin is bright and ah. This inaccuracy resulted in the demand by the Party of the late PPAT Sadnam Mairin Khana to as Party co-defendant. In Wonosobo Religious Court decision No. 4 / Pdt.G / 2017 / PN Wsb dated June 20, 2017 which was later upheld by the High Court of Semarang No. 332 / PDT / 2017 / PT.Smg dated October 16, 2017 has been taken into consideration to decide the Chief Justice the Supreme Court decision No. 826 K / Pdt / 2018 states that according to the law, the act Co-Defendant II (PPAT officials) who have made and published the Sale and Purchase Agreements No. 186/2015 dated March 9, 2015 is an unlawful act.

In the law known three (3) categories of tort, the tort willful misconduct, tort without an error (without the element of intent or negligence) and tort for negligence. ${ }^{18}$ Regarding the responsibilities of the deed containing PPAT is the responsibility of the administrative

\footnotetext{
${ }^{17}$ Peter Mahmud Marzuki, 2006, Penelitian Hukum, Jakarta: Kencana, p. 25

${ }^{18}$ Soegianto, 2015, Etika Profesi dan Perlindungan Hukum Bagi Notaris, Yogyakarta: CV. Farisma Indonesia, p. 85
} 
Volume 7 Issue 1, March 2020

Nationally Accredited Journal,

Decree No. B/4130/E5/E5.2.1/2019

disputes, to civil and criminal. ${ }^{19}$

Based on the above land dispute, that the making of the deed of sale before PPAT is invalid, because the transaction is not based on faith thathonest from the Defendant and Co-Defendant II. it also resulted PPAT involved in tort. As a result of the law of Supreme Court Decision No. 826 K / Pdt / 2018 against the Land Deed Official (PPAT) who manufacture Sale and Purchase Agreements Land Dispute Number 186/2015 and certificate of land with 1394 numbers into null and void and has no legal force binding. Whereas in Article 10 paragraph (3) PPAT be dishonorably discharged. In the case that the author analyzes the causes of PPAT in verdict sentenced to commit an unlawful act is a deed over land rights / Right of Ownership on Unit Flats Disputes. The object still is in accordance with the provisions of the explanation of government regulation number 24 2016 number 8, and including in the category of crimes. Therefore, according to the Government Regulation Number 24 of 2016 Article 10 paragraph (2), co-defendant II (PPAT) may be liable to dismissal in disgrace.

\section{Closing}

\subsection{Conclusion}

- Liabilities PPAT is a deed as evidence has implemented certain legal actions regarding land rights or ownership of the apartment units in this case the sale and purchase of land, then PPAT registration certificate under the name of the seller into the buyer's name. The obligation of PPAT in making the deed of sale and purchase agreements are researching their position or status sellers of land, to make sure that the seller is the party authorized to sell the land, to make sure that the buyer is the party according to the law and ensure that the object of land to be sold is not the land status dispute. Deed of sale should not be made by PPAT are not in the working area, in accordance with Article 12 paragraph (1) of Government Regulation No. 37 of 1998.

- The validity of the deed of PPAT regulated and determined by the Minister is now the National Land Agency, it is affirmed in Article 21 paragraph (1) of Government Regulation No. 37 of 1998 which states that the Deed PPAT made in the prescribed form of the National Land Agency and the explanation is confirmed to qualify authentic a deed then PPAT Deed shall be determined by the shape of the National Land Agency.

- result law The Supreme Court decision No. 826 K / Pdt / 2018 is the Deed of Sale and Purchase of Land Disputes number 186/2015 and certificate of land with 1394 numbers became invalid / void and not legally binding. PPAT deed that makes the deed of sale and the Land Board that issued certificates on the dispute objects categorized tort. PPAT deeds mentioned in Article 21 paragraph (1) of Government Regulation No. 37 of 1998 , including violations of the type of heavy and can be sentenced dishonorably discharged from his post.

\subsection{Suggestion}

National Land Agency should further improve guidance to the Land Deed Official (PPAT), the Land Deed Official (PPAT) in making a deed of sale of land to be meticulous, careful, cautious, and should not be careless. While those communities should be more honest in

\footnotetext{
${ }^{19}$ Dhona Cristin, 2017, Analisis Atas Diketahuinya Cacat Yuridis Pada Akta Jual Beli Tanah Dan Rumah Yang Dibuat Oleh PPAT, North Sumatra: USU Journal Vol 14 (2017) of North Sumatra University, p. 12
} 
eISSN : 2581-2114, pISSN: 2406-9426

performing a legal act.

\section{References}

\section{Book}

[1] Abdul Ghofur Anshori 2006, Pokok-pokok Hukum Perjanjian Islam di Indonesia, Yogyakarta: Citra Media

[2] Abdul Kadir Muhammad, 1994, Hukum Harta Kekayaan, First Edition, Bandung: Citra Aditya Bakti

[3] Adrian Sutedi 2010, Peralihan Hak Atas Tanah Dan Pendaftarannya, Issue 1, fourth Molds, Jakarta: Sinar Grafika

[4] Adrian Sutedi, 2012, Sertifikat Hak Atas Tanah, Jakarta: Sinar Grafika

[5] Dhona Cristin, 2017, Analisis Atas Diketahuinya Cacat Yuridis Pada Akta Jual Beli Tanah Dan Rumah Yang Dibuat Oleh PPAT, North Sumatra : USU Journal Vol 14 (2017) of North Sumatra University

[6] Effendi Perangin, 1990, Praktik jual Beli Tanah, Second Edition, Jakarta: Rajawali

[7] Harun al-Rashid, 1987, Sekilas tentang jual Beli Tanah, First Edition, Jakarta: Ghalia Indonesia

[8] Irawan Soerodjo, 2003, Kepastian Hukum Hak Atas Tanah di Indonesia, First Edition, Surabaya: Arkola

[9] Kartini Mulyadi and Gunawan Wijaya 2005, Hak Tanggungan, Issue I, Jakarta: Prenada Media

[10] Mark P. Thompson, 2001, the Modern Land Law, First Published, Oxford University Press, New York

[11] Purnama Tioria Sian 2008, Perlindungan Hukum Terhadap Pembeli Barang Jaminan Tidak Bergerak Melalui Lelang, Bandung: Mandar Maju Publisher

[12] Rachmadi Usman, 2003, Pilihan Penyelesaian Sengketa di Luar Pengadilan, Bandung: PT. Citra Aditya Bakri

[13] Rosa Agustina 2003, Perbuatan Melawan Hukum, Jakarta: University of Indonesia

[14] Rusdi Malik, 2000, Penemu Agama Dalam Hukum, Jakarta: Trisakti

[15] Soegianto, 2015, Etika Profesi dan Perlindungan Hukum Bagi Notaris, Yogyakarta: CV. Farisma Indonesia

\section{Laws and regulations}

[1] Government Regulation No. 38 of 1963 on the appointment of Legal Persons to Have Properties Land

[2] Government Regulation No. 24 of 1997 on Land Registration 2

[3] Regulation of the Minister of Agriculture of the National Land Agency Number 4 of 1999

[4] Government Regulation No. 24 of 2016 on the Land Deed Official

[5] Government Regulation No. 37 of 1998 on the Land Deed Official Position

[6] Government Regulation No. 24 of 2016 on the amendment to Government Regulation No. 37 Year 1998 on the regulations Land Deed Official Position

[7] Supreme Court Decision No. 826 / k / Pdt / 2018 